\title{
Transport of thyroid hormone in brain
}

\author{
Eva K. Wirth ${ }^{1}$, Ulrich Schweizer ${ }^{2}$ and Josef Köhrle ${ }^{1}{ }^{*}$ \\ 1 Institut für Experimentelle Endokrinologie, Charité-Universitätsmedizin Berlin, Berlin, Germany \\ ${ }^{2}$ Institut für Biochemie und Molekularbiologie, Rheinische Friedrich-Wilhelms-Universität Bonn, Bonn, Germany
}

Edited by:

Noriyuki Koibuchi, Gunma University

Graduate School of Medicine, Japan

\section{Reviewed by:}

Takashi Yoshimura, Nagoya University, Japan

Heike Heuer, Leibniz Institute for Age

Research-Fritz Lipmann Institute,

Germany

\section{*Correspondence:}

Josef Köhrle, Institut für

Experimentelle Endokrinologie, Charité-Universitätsmedizin Berlin,

Augustenburger Platz 1, Berlin 13353,

Germany

e-mail: josef.koehrle@charite.de
Thyroid hormone (TH) transport into the brain is not only pivotal for development and differentiation, but also for maintenance and regulation of adult central nervous system (CNS) function. In this review, we highlight some key factors and structures regulating TH uptake and distribution. Serum $\mathrm{TH}$ binding proteins play a major role for the availability of $\mathrm{TH}$ since only free hormone concentrations may dictate cellular uptake. One of these proteins, transthyretin is also present in the cerebrospinal fluid (CSF) after being secreted by the choroid plexus. Entry routes into the brain like the blood-brain-barrier (BBB) and the blood-CSF-barrier will be explicated regarding fetal and adult status. Recently identified TH transmembrane transporters (THTT) like monocarboxylate transporter 8 (Mct8) play a major role in uptake of TH across the BBB but as well in transport between cells like astrocytes and neurons within the brain. Species differences in transporter expression will be presented and interference of $\mathrm{TH}$ transport by endogenous and exogenous compounds including endocrine disruptors and drugs will be discussed.

Keywords: blood-brain-barrier, transthyretin, deiodinase, flavonoids, endocrine disruptors, Mct8, L-type amino acid transporter, organic anion transporters

\section{MOLECULES INVOLVED IN TH TRANSPORT IN THE BRAIN}

The hydrophobic but amphipathic charged amino acid-derived thyroid hormones $(\mathrm{TH})$ are carried and distributed by several binding proteins from their site of production, storage, and secretion, the thyroid gland, to their target tissues including the brain. In human blood, four major proteins, thyroxine-binding globulin (TBG), transthyretin (TTR), albumin, and apolipoprotein B 100 (ApoB100), bind more than $99 \%$ of the circulating $\mathrm{TH} \mathrm{T}_{4}, \mathrm{~T}_{3}$, and 3-iodo-thyronamine (3-T1AM). In contrast, only TTR has been found as one of the main proteins in CSF where it is produced and directionally secreted by choroid plexus (CP) epithelial cells into the liquor, which does not contain the high affinity TBG or the high capacity albumin TH binding proteins. Whether 3-T1AM, a $\mathrm{TH}$-derived biogenic amine and its high affinity binding protein ApoB100 occur in CSF, remains to be studied.

Thyroid hormone enters the brain either directly via the bloodbrain barrier (BBB) or indirectly via the blood-CSF-barrier (BCSF-B), with the BBB route as the major entry path for the prohormone $T_{4} . T_{4}$ is locally metabolized by selenoenzymes to either active $\mathrm{T}_{3}$ via Type 2 deiodinase (Dio2) or inactivated by Type 3 deiodinase (Dio3), to yield reverse $\mathrm{T}_{3}\left(\mathrm{rT}_{3}\right) . \mathrm{rT}_{3}$, devoid of $\mathrm{T}_{3}$-like action, might be involved in developmental regulation of neuronal migration guided by astrocytes and glial cells (1). Dio2 is mostly expressed in astrocytes and tanycytes while Dio3 is mainly found in neurons. Whether Type 1 deiodinase (Dio1), catalyzing both $5^{\prime}$-deiodination (activation of $\mathrm{T}_{4}$ to $\mathrm{T}_{3}$ ) and 5-deiodination (inactivation of $\mathrm{T}_{4}$ and $\mathrm{T}_{3}$ ) is species-dependently expressed in brain remains controversial $(2,3)$. Dual entry paths of TH and cell type-specific expression of functional Dio enzymes in the brain raise the issues of (i) coordinated transport of active $\mathrm{TH}$ and TH metabolites between various brain cell types, (ii) organized communication between peripheral, thyroid-derived, and brain
$\mathrm{TH}$, and (iii) demands, supply, and disposal of TH precursors, metabolites, and active TH.

Adequate TH supply for the brain is of eminent importance during development but not less relevant in the differentiated adult organism with its changing hormonal requirement for metabolic and environmental adaptation.

Components controlling $\mathrm{TH}$ availability and action have been described in brain stem and progenitor cells (4) and TH receptor (TR) expression in the human brain has been demonstrated decades ago (5). Already during the first trimester human brain expresses various TH transporters (see Table 1), Dio enzymes, TRisoforms, and isotypes in a development- and cell type-specific manner. Later in human pregnancy during weeks $17-20$, endothelial cells and astrocytes organize the BBB [see Ref. (6)]. Endothelial cells express the TH transporter organic anion transporter polypeptide 1C1 (OATP1C1), which limits brain access of $\mathrm{TH}$, especially $\mathrm{T}_{4}$. At this time point fetal thyroid already starts producing $\mathrm{TH}$, thus disconnecting the fetal $\mathrm{TH}$ responsive system from the maternal source of $\mathrm{TH}$, but still depending on further adequate maternal iodide supply.

Facilitated uptake and release of $\mathrm{TH}$ by $\mathrm{TH}$ transmembrane transporters (THTT) is essential for their intracellular availability. TH have to cross multiple membranes in order to reach their nuclear and mitochondrial receptors. Especially, the entry of TH into the brain via the $\mathrm{BBB}$ and their subsequent distribution throughout all brain areas poses challenges in form of membranes of different cell types to be crossed. The complex interaction and communication between astrocytes and neurons, demonstrated for metabolic as well as synaptic processes, is in place regarding $\mathrm{TH}$ metabolism and distribution throughout the brain. Therefore, the specific spatio-temporal distribution of $\mathrm{TH}$ in different areas and cell types of the brain is required during embryonic development 
Table 1 | Summary of expression profiles of thyroid hormone transmembrane transporters (THTT) in various cell types of the brain of several species.

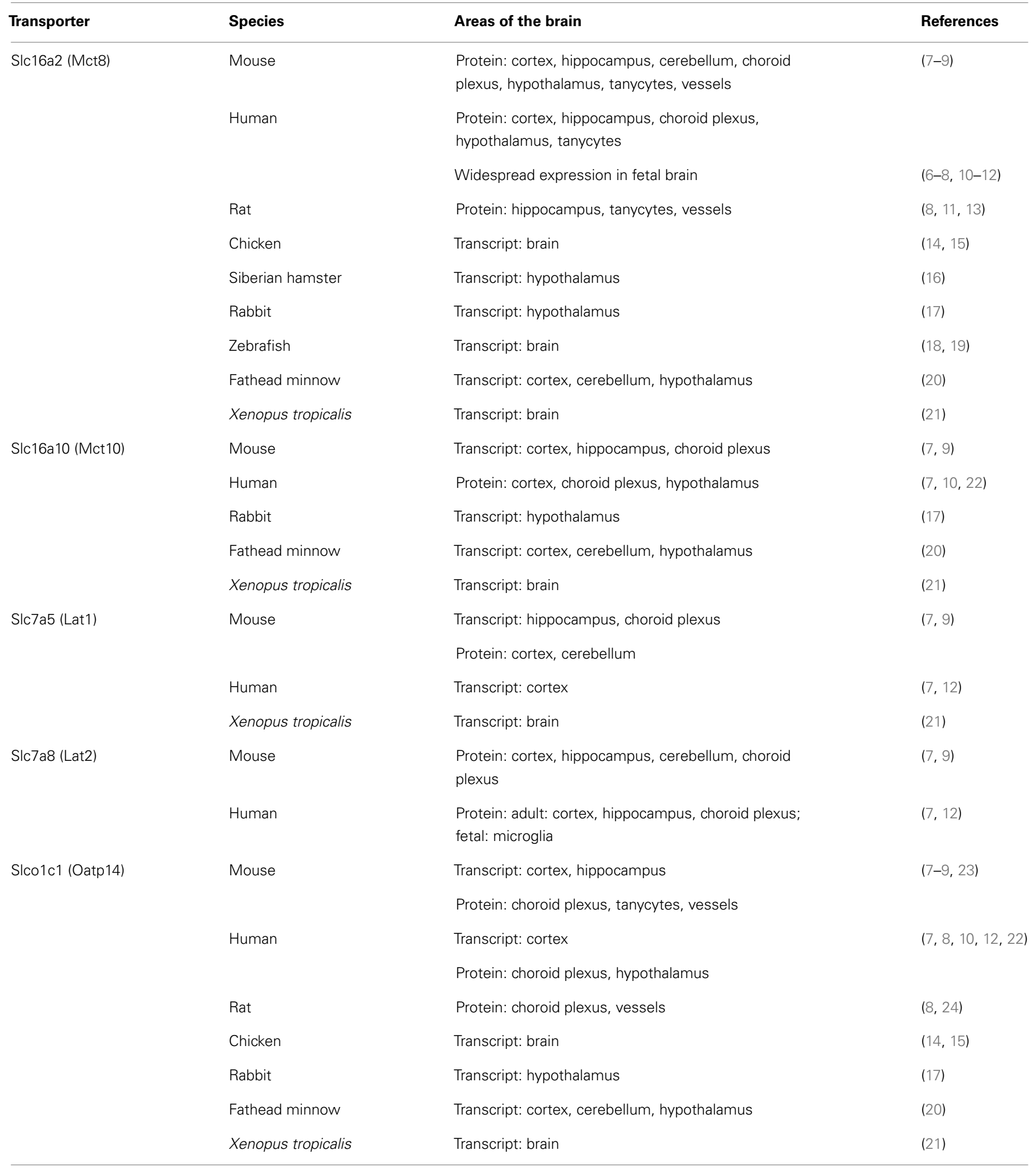

If available, protein data is preferably mentioned. Transcript data is only mentioned if no or only minimal protein data is available. 
and differentiation, but also for adult maintenance and regulation of brain activity and metabolism.

\section{ROLE OF TH BINDING AND DISTRIBUTOR PROTEINS FOR TH AVAILABILITY TO BRAIN CELLS}

Tissue and cellular uptake depends on free TH concentrations in blood and both free $T_{4}$ and free $T_{3}$ are available for cellular uptake by THTT, while TH bound with high affinity to serum distributor proteins TBG and TTR is assumed not to be directly available for cellular uptake during organ perfusion by blood (25). In contrast, TH bound to albumin with high capacity but low affinity is easily liberated based on the high TH off-rate constants shown in liver perfusion $(26,27)$. While peripheral sensory neurons internalize TTR in megalin-dependent manner in context of neuritogenesis in vitro (28), evidence is missing, that TH-TTR ligand-protein complexes are taken up by neurons, astrocytes, or glial cells via receptors for these proteins expressed on brain cells. Such "trojan horse" mechanisms of ligand transmembrane transfer have been demonstrated during fetal development for several protein bound (pro-)hormones and vitamins such as TH, retinol, vitamin D3, and steroid hormones (29-31) for several peripheral target tissues including adult kidney but not yet for the fetal brain. Such mechanisms, mediated by megalin or cubilin receptors, might provide entry routes for hormones bypassing the concept of the "free hormone hypothesis" (32) and use of THTT.

Independent from such a mechanism, the high expression of evolutionary conserved TTR in CP and meninges of the developing and adult brain offers a further exchange compartment for TH, especially $\mathrm{T}_{4}$, a high affinity ligand of TTR. During fetal brain development, the prominent voluminous $\mathrm{CP}$ is required for proper CNS growth and differentiation. TTR is the only TH binding protein expressed and directionally secreted into CSF. TTR, first described in CSF and subsequently in plasma, constitutes up to $20 \%$ of CSF protein and its secretion into CSF starts already in fetal week 8 before its hepatic production (28). Whether its adequate function as binding and distribution protein for two major morphogen precursors, $\mathrm{T}_{4}$ and RBP-bound retinol, is essential or redundant, remains to be established. Lack of a major phenotype of TTR gene inactivation in the mouse came as a surprise with respect to normal brain development, HPT axis, TH homeostasis, and retinol-dependent functions (33). These mice grew normal, were fertile and had normal tissue $\mathrm{T}_{4}$ levels though plasma $\mathrm{TH}$ concentrations were significantly reduced. Apparently, lack of TTR can be compensated by a shift of TH binding to rodent TBG, which has lower TH affinity compared to human TBG (34). TH metabolism and $\mathrm{T}_{3}$-responsive gene expression of HPT axis and liver was unchanged in TTR knock-out mice. These observations either suggest a minor role for TTR-dependent TH binding and directional transport into CSF for proper brain development (35) or indicate existence of still unknown compensatory mechanisms active in absence of TTR during mouse development. At least this mouse model did not support the hypothesis that hormone binding and distribution proteins such as TTR in case of TH directly contribute to cellular hormone uptake as proposed by Pardridge (36) in distinction to several observations by the group of Willnow (31).

In contrast to these observations in the TTR knock-out mouse model are some findings on effects of endogenous or exogenous ligands of TTR, such as (iso-)flavonoids and endocrine disruptors, interfering with TH homeostasis in circulation, in CNS, and during fetal development. Several natural flavonoids, secondary metabolites of plants contained in our regular diet, avidly bind to TTR and displace TH from TTR binding based on their structural resemblance to $\mathrm{TH}$. Resulting elevated free $\mathrm{TH}$ blood concentrations increase renal TH loss (transiently), elevate TH tissues levels, and enhance TH transfer via the placenta into fetal circulation including the fetal brain. In vitro as well as rodent animal studies provided evidence for interference of flavonoids and other TTR binding endocrine disruptors with CP-derived TTR-mediated TH transfer into CSF and the brain, resulting in disturbed homeostasis of brain TH levels and bioavailability (37).

More studies are needed analyzing (i) interference by natural and synthetic flavonoids with TH transport, (ii) action of endocrine disrupters such as the flame retardants polybrominated diphenylethers (PBDE) during neuronal stem cell development (38), or (iii) impact of ligands and pharmaceuticals, structurally related to TH (39) and interfering with THTT function (40). Recently, molecular actions and biological functions have been initially characterized for so far "neglected or minor" endogenous TH metabolites such as acetic acid- (Tetrac, Triac) or aminederivatives (3-T1AM) of TH (41) and 3,5-T2, the latter abundantly present in the CNS (42). This raises the questions, (i) whether they are active players in TH-regulated brain function during development and in the adult organism, (ii) whether and how these metabolites are generated and transported in the brain, and (iii) how their mode of action interferes with classical $\mathrm{TH}$ action, which is mainly mediated via $\mathrm{T}_{3}$-liganded $\mathrm{TR}$. New modes of action may be envisaged for these TH metabolites at the plasma membrane, on cytosolic signaling cascades, or on other subcellular compartments of brain cells (43-45).

\section{THTT AMONG SPECIES}

Many transporters have been shown to transport TH. The most specific THTT is the monocarboxylate transporter 8 (Mct8; Slc16a2). Up to date, it is the only transporter with $\mathrm{TH}$ as the exclusive substrate. All other transporters out of the classes of monocarboxylate transporters (MCT), organic anion transporting polypeptides (OATP), and L-type amino acid transporters (LAT) also transport other substrates like amino acids. Most data about the presence and localization of THTT has been generated in mice and humans. The following table summarizes expression of the most researched THTT Mct8, Mct10, Lat1, Lat2, and Oatp1c1 in various vertebrate species (Table 1).

Research focus has been on the only THTT identified to cause a human disease so far, i.e., Mct8. MCT8 is widely expressed in the human fetal brain in several cell types (Table 1). Strong transcript and protein signals were observed in the cortical plate and subplate, as well as in ventricular and subventricular zones. Throughout fetal development $\mathrm{CP}$ epithelial cells and ependymal cells express high levels of MCT8 (6-8).

Comparably high MCT8 expression has been reported for monkey brain, which expresses OATP1C1 and LAT1 albeit at much lower levels (46). MCT8 mutations cause a severe syndrome of psychomotor retardation, the Allan-Herndon-Dudley syndrome (AHDS) (47-50). This syndrome also comprises endocrine 
manifestations with high circulating $\mathrm{T}_{3}$, low $\mathrm{T}_{4}$, and normal to elevated TSH levels. The mouse model for Mct8-deficiency replicates the endocrine phenotype, but it does not mimic the psychomotor retardation of the human syndrome $(7,51,52)$. Since AHDS is not comparable to the classical phenotype of congenital hypothyroidism or cretinism, it is of great importance to identify THTT in brain areas of human brains, as well as in the model organism used for analyzing $\mathrm{TH}$ transport to be able to understand phenotypic variations between these models. Other animal models apart from Mct8-deficient mice will be needed to evaluate the involvement of THTT in basic brain development. Recently, zebrafish has been evaluated for developmental effects of Mct8-deficiency. Significant species differences with respect to cell types, time point, dynamics, and regulation of THTT especially in the developing but also the adult brain have been reported for humans, monkey, chicken, rodent, fish, and amphibian brain (Table 1). For example, we demonstrated the expression of an additional transporter, Lat2, in mouse neurons during development, which is not expressed in human developing neurons (7). Research on double knock-out mice of Mct8 with either Mct10 or Oatplc1 yielded valuable data on the interplay and possible compensation between these transporters $(53,54)$. Simultaneous deletion of Mct8 and Oatp1c1 lead to the ablation of both $\mathrm{T}_{3}$ and $\mathrm{T}_{4}$ transport across BBB. Symptoms of brain hypothyroidism were intensified underlining the importance of THTT for proper brain development and function. Further research analyzing the developmental expression of THTT and comparing effects of loss of function among different species will yield important information on the temporal effects of these transporters on brain development.

\section{STRUCTURAL ASPECTS OF THTT}

Thyroid hormone transport proteins MCT8, MCT10, OATP1C1, as well as LAT1 and LAT2 belong to different subfamilies within a huge protein superfamily of transport proteins, the major facilitator superfamily, MFS (55). General insights into the function of such transmembrane proteins can be derived from pathogenic mutations, e.g., in MCT8 from patients affected by AHDS (56).

Substrate recognition by transport proteins is fundamentally different from ligand binding in, e.g., nuclear receptors: while receptors are optimized for high affinity binding of their ligands, this would be detrimental for transporters, as these have to release their substrates easily. Most receptors have one binding site, while THTT should have at least two - one accessible from the exterior and one accessible form the interior of the cell. These two binding sites may overlap and differ only according to conformational changes associated with transport. The question is thus, how can a transporter achieve specificity and at the same time prevent tight binding?

With the exception of MCT8, all other THTT transport additional substrates, namely amino acids, bile acids, or conjugated steroids. It should therefore be of particular interest to compare how different protein families have adapted to transport $\mathrm{TH}$ and whether the substrate-protein interactions are similar or not. Experimental structures are not available for any of the THTT. Homology models based on experimental structures have been created for OATP1C1 (57), MCT8 (39), and LAT1 (58).
The homology model of rat Oatp1c1 was based on three high resolution crystal structures of bacterial transport proteins, lactose permease LacY, glycerol-phosphate transporter GlpT, and multidrug resistance protein EmrD. Authors achieved similar models with all templates and highlighted sequence identities between Oatp1c1 and templates below 10\%. Conserved amino acids between Oatp1c1 and bacterial transporters were known to be functionally important in LacY and GlpT and may therefore not be involved in substrate specificity. While this work nicely shows that Oatp1c1 conforms to the overall structure of the bacterial transporters, there is no information on how specificity is established (57).

Chemical probes reactive with cysteines ( $p$-chloromercury benzenesulfonate, pCMBS) or histidines (diethylpyrocarbonate, DEPC) were used to modify MCT8 and to test its activity afterward $(59,60)$. This approach suggested that Cys481, Cys497, and His 192 may be close to the substrate translocation channel. Mutation to Ala of these critical amino acids rendered MCT8 resistant to pCMBS and DEPC.

We created a MCT8 homology model based on the inward-open conformation of GlpT and identified two charged amino acids within the transmembrane domains, Asp498 and Arg445, which are essential for transport (39). The homology model predicted a salt bridge between both residues. We suggested interaction of TH carboxyl and amino groups with these amino acids during transport, since $\mathrm{TH}$ analogs lacking the carboxyl or amino groups are not transported by MCT8 (39). The salt bridge was later independently confirmed by charge reversal mutants (61). MCT8 accepts only L-T $\mathrm{T}_{3}, \mathrm{~L}-\mathrm{T}_{4}, \mathrm{~L}-\mathrm{rT}_{3}$, and L-3,3'- $\mathrm{T}_{2}$ as substrates (39). Based on the occurrence of a His-Arg clamp pinching $\mathrm{T}_{3}$ in the $\mathrm{T} 3$ receptor $\beta$ structure, we tested the hypothesis that a His-Arg pair spaced by about $15 \AA$ could serve the same purpose in MCT8 (62). Mutation of His192 (which may work together with Arg445 in an outward open conformation) clearly demonstrated His 192 participation in substrate recognition (63). Interestingly, His192 corresponds to Gln88 in MCT10, a closely related homolog of MCT8 unable to transport $\mathrm{T}_{4}$ (64). Mutation of His415 and Arg301, conserved in MCT8 and MCT10, affected transport kinetics as expected from substrate interactions (63). These findings corroborate the usefulness of the MCT8 homology model and suggest how the substrate is bound by MCT8 - at least in the inward-open conformation.

Recently, a LAT1 homology model was presented based on the crystal structure of bacterial agmatine antiporter AdiC (58). Iodotyrosines were identified in silico as LAT1 substrates and confirmed experimentally. Interestingly, while carboxy and amino groups are present in all LAT1 substrates, modeling suggests that these functions are sampled by the transporter by backbone polar contacts instead of side chain contacts as predicted in MCT8 (58, 63). Different transporters may have adapted different strategies to recognize iodinated $\mathrm{TH}$ substrates.

\section{THTT IN CELL TYPES OF THE BRAIN}

Analyses of brain regions provide important insight into THTT distribution. Immunohistochemical staining for Mct8 in mouse brains did not only show typical neuronal staining patterns, but also staining in astrocytes, CP, and tanycytes (7). However, most techniques like in situ hybridization or immunohistochemistry 
do not allow for a real cell type-specific resolution and detection. Effects of TH uptake into neurons vs. astrocytes can not be dissected in complete brains. Primary cultures of mouse brain cells facilitate selection of a single cell type and the evaluation of effects of THTT deletion. Primary cultures of mouse neurons, astrocytes, and microglia can be used to detect THTT expression and functionality, as well as the reaction of specific cells on different conditions of TH access. Genetically engineered mouse lines can be used to create cell cultures originating from wildtype and transporter-deficient mice. Employing these cultures, we detected expression of Mct8, Lat1, and Lat2 transcripts and proteins in neurons and astrocytes, while Lat2 is additionally expressed in microglia $(9,65)$. Functional uptake studies in Mct8- and Lat2deficient primary neuronal and astrocyte cell cultures demonstrated involvement of both transporters in $\mathrm{T}_{3}$ and $\mathrm{T}_{4}$ uptake into neurons and astrocytes $(7,9)$. The fraction of $\mathrm{TH}$ uptake mediated by transporters of the Mct, Lat, and Oatp groups can also be monitored by utilizing inhibitors of these transporters. Transport by Mct can be inhibited with bromosulphophtalein (BSP), while 2-aminobicyclo-(2,2,1)-heptane-2-carboxylic acid (BCH) is a Lat inhibitor and probenicid inhibits transport by Oatps. Uptake studies with these inhibitors gave very similar results on the involvement of these groups of transporters in TH uptake to genetic inactivation $(7,9)$.

Up to date, all concepts of interaction and cooperation between neurons and astrocytes imply astrocytes as providers of energy, communication and $\mathrm{T}_{3}$ for neurons. However, it has been shown that neurons are generally able to carry out all functions needed for energy metabolism by themselves. It is therefore quite possible that neurons are able to convert $\mathrm{T}_{4}$ to $\mathrm{T}_{3}$ by expressing functional Dio2. Cell type-specific animal models and primary cell cultures are of great importance to study the interaction of neurons and astrocytes regarding transfer of $\mathrm{TH}$ metabolites and regulation of deiodinases independent of TH uptake at the BBB.

\section{ACKNOWLEDGMENTS}

Eva K. Wirth, Ulrich Schweizer, and Josef Köhrle were supported by funding of the Deutsche Forschungsgemeinschaft (WI3768/11, WI3768/2-1, KO922/16-1, GRK1208/2 TP3, Schw914/3-1, and SPP 1629 ThyroidTransAct).

\section{REFERENCES}

1. Farwell AP, Dubord-Tomasetti SA, Pietrzykowski AZ, Stachelek SJ, Leonard JL. Regulation of cerebellar neuronal migration and neurite outgrowth by thyroxine and 3,3',5' -triiodothyronine. Brain Res Dev Brain Res (2005) 154(1):121-35. doi:10.1016/j.devbrainres.2004.07.016

2. Visser TJ, Leonard JL, Kaplan MM, Larsen PR. Kinetic evidence suggesting two mechanisms for iodothyronine $5^{\prime}$-deiodination in rat cerebral cortex. Proc Natl Acad Sci U S A (1982) 79(16):5080-4. doi:10.1073/pnas.79.16.5080

3. Verhoelst CH, Roelens SA, Darras VM. Role of spatiotemporal expression of iodothyronine deiodinase proteins in cerebellar cell organization. Brain Res Bull (2005) 67(3):196-202. doi:10.1016/j.brainresbull.2005.06.030

4. Lemkine GF, Raj A, Alfama G, Turque N, Hassani Z, Alegria-Prevot O, et al. Adult neural stem cell cycling in vivo requires thyroid hormone and its alpha receptor. FASEB J (2005) 19(7):863-5. doi:10.1096/fj.04-2916fje

5. Bernal J, Pekonen F. Ontogenesis of the nuclear 3,5,3'-triiodothyronine receptor in the human fetal brain. Endocrinology (1984) 114(2):677-9. doi:10.1210/ endo-114-2-677

6. Chan SY, Hancox LA, Martin-Santos A, Loubiere LS, Walter MN, Gonzalez AM, et al. MCT8 expression in human fetal cerebral cortex is reduced in severe intrauterine growth restriction. J Endocrinol (2014) 220(2):85-95. doi:10.1530/JOE-13-0400

7. Wirth EK, Roth S, Blechschmidt C, Hölter SM, Becker L, Racz I, et al. Neuronal 3',3,5-triiodothyronine (T3) uptake and behavioral phenotype of mice deficient in Mct8, the neuronal T3 transporter mutated in Allan-Herndon-Dudley syndrome. J Neurosci (2009) 29(30):9439-49. doi:10.1523/JNEUROSCI.6055-08. 2009 Epub 2009/07/31,

8. Roberts LM, Woodford K, Zhou M, Black DS, Haggerty JE, Tate EH, et al. Expression of the thyroid hormone transporters monocarboxylate transporter8 (SLC16A2) and organic ion transporter-14 (SLCO1C1) at the blood-brain barrier. Endocrinology (2008) 149(12):6251-61. doi:10.1210/en.2008-0378

9. Braun D, Kinne A, Bräuer AU, Sapin R, Klein MO, Köhrle J, et al. Developmental and cell type-specific expression of thyroid hormone transporters in the mouse brain and in primary brain cells. Glia (2011) 59(3):463-71. doi:10.1002/glia.21116 Epub 2011/01/26,

10. Friesema EC, Visser TJ, Borgers AJ, Kalsbeek A, Swaab DF, Fliers E, et al. Thyroid hormone transporters and deiodinases in the developing human hypothalamus. Eur J Endocrinol (2012) 167(3):379-86. doi:10.1530/EJE-12-0177

11. Kallo I, Mohacsik P, Vida B, Zeold A, Bardoczi Z, Zavacki AM, et al. A novel pathway regulates thyroid hormone availability in rat and human hypothalamic neurosecretory neurons. PLoS One (2012) 7(6):e37860. doi:10.1371/journal. pone. 0037860

12. Chan SY, Martin-Santos A, Loubiere LS, Gonzalez AM, Stieger B, Logan A, et al. The expression of thyroid hormone transporters in the human fetal cerebral cortex during early development and in N-Tera-2 neurodifferentiation. J Physiol (2011) 589(Pt 11):2827-45. doi:10.1113/jphysiol.2011.207290 Epub 2011/04/14,

13. Sharlin DS, Gilbert ME, Taylor MA, Ferguson DC, Zoeller RT. The nature of the compensatory response to low thyroid hormone in the developing brain. J Neuroendocrinol (2010) 22(3):153-65. doi:10.1111/j.1365-2826.2009.01947.x Epub 2010/01/01,

14. Geysens S, Ferran JL, Van Herck SL, Tylzanowski P, Puelles L, Darras VM. Dynamic mRNA distribution pattern of thyroid hormone transporters and deiodinases during early embryonic chicken brain development. Neuroscience (2012) 221:69-85. doi:10.1016/j.neuroscience.2012.06.057

15. Van Herck SL, Geysens S, Delbaere J, Tylzanowski P, Darras VM. Expression profile and thyroid hormone responsiveness of transporters and deiodinases in early embryonic chicken brain development. Mol Cell Endocrinol (2012) 349(2):289-97. doi:10.1016/j.mce.2011.11.012

16. Herwig A, de Vries EM, Bolborea M, Wilson D, Mercer JG, Ebling FJ, et al. Hypothalamic ventricular ependymal thyroid hormone deiodinases are an important element of circannual timing in the Siberian hamster (Phodopus sungorus). PLoS One (2013) 8(4):e62003. doi:10.1371/journal.pone.0062003

17. Mebis L, Debaveye Y, Ellger B, Derde S, Ververs EJ, Langouche L, et al. Changes in the central component of the hypothalamus-pituitary-thyroid axis in a rabbit model of prolonged critical illness. Crit Care (2009) 13(5):R147. doi:10.1186/cc8043

18. Arjona FJ, de Vrieze E, Visser TJ, Flik G, Klaren PH. Identification and functional characterization of zebrafish solute carrier Slc16a2 (Mct8) as a thyroid hormone membrane transporter. Endocrinology (2011) 152(12):5065-73. doi:10.1210/en.2011-1166

19. Vatine GD, Zada D, Lerer-Goldshtein T, Tovin A, Malkinson G, Yaniv K, et al. Zebrafish as a model for monocarboxyl transporter 8-deficiency. J Biol Chem (2013) 288(1):169-80. doi:10.1074/jbc.M112.413831

20. Muzzio AM, Noyes PD, Stapleton HM, Lema SC. Tissue distribution and thyroid hormone effects on mRNA abundance for membrane transporters Mct8, Mct10, and organic anion-transporting polypeptides (Oatps) in a teleost fish. Comp Biochem Physiol A Mol Integr Physiol (2014) 167:77-89. doi:10.1016/j. cbpa.2013.09.019

21. Connors KA, Korte JJ, Anderson GW, Degitz SJ. Characterization of thyroid hormone transporter expression during tissue-specific metamorphic events in Xenopus tropicalis. Gen Comp Endocrinol (2010) 168(1):149-59. doi:10.1016/j. ygcen.2010.04.015 Epub 2010/04/27,

22. Alkemade A, Friesema EC, Kalsbeek A, Swaab DF, Visser TJ, Fliers E. Expression of thyroid hormone transporters in the human hypothalamus. J Clin Endocrinol Metab (2011) 96(6):E967-71. doi:10.1210/jc.2010-2750

23. Tohyama K, Kusuhara H, Sugiyama Y. Involvement of multispecific organic anion transporter, Oatp14 (Slc21a14), in the transport of thyroxine across the blood-brain barrier. Endocrinology (2004) 145(9):4384-91. doi:10.1210/en. 2004-0058 
24. Sugiyama D, Kusuhara H, Taniguchi H, Ishikawa S, Nozaki Y, Aburatani H, et al. Functional characterization of rat brain-specific organic anion transporter (Oatp14) at the blood-brain barrier: high affinity transporter for thyroxine. J Biol Chem (2003) 278(44):43489-95. doi:10.1074/jbc.M306933200

25. Richardson SJ. Evolutionary changes to transthyretin: evolution of transthyretin biosynthesis. FEBS J (2009) 276(19):5342-56. doi:10.1111/j.1742-4658.2009. 07244.x

26. Mendel CM, Weisiger RA, Jones AL, Cavalieri RR. Thyroid hormone-binding proteins in plasma facilitate uniform distribution of thyroxine within tissues: a perfused rat liver study. Endocrinology (1987) 120(5):1742-9. doi:10.1210/ endo-120-5-1742

27. Richardson SJ. Cell and molecular biology of transthyretin and thyroid hormones. Int Rev Cytol (2007) 258:137-93. doi:10.1016/S0074-7696(07)58003-4

28. Fleming CE, Mar FM, Franquinho F, Saraiva MJ, Sousa MM. Transthyretin internalization by sensory neurons is megalin mediated and necessary for its neuritogenic activity. J Neurosci (2009) 29(10):3220-32. doi:10.1523/JNEUROSCI. 6012-08.2009

29. Sousa MM, Norden AG, Jacobsen C, Willnow TE, Christensen EI, Thakker RV, et al. Evidence for the role of megalin in renal uptake of transthyretin. J Biol Chem (2000) 275(49):38176-81. doi:10.1074/jbc.M002886200

30. Willnow TE, Hammes A, Nykjaer A. Endocytosis of sex steroids: the hypothesis of free hormones revisited. Ann Endocrinol (Paris) (2008) 69(2):101-2. doi:10.1016/j.ando.2008.02.024

31. Willnow TE, Nykjaer A. Cellular uptake of steroid carrier proteins - mechanisms and implications. Mol Cell Endocrinol (2010) 316(1):93-102. doi:10.1016/j.mce. 2009.07.021

32. Mendel CM. The free hormone hypothesis. Distinction from the free hormone transport hypothesis. J Androl (1992) 13(2):107-16.

33. Episkopou V, Maeda S, Nishiguchi S, Shimada K, Gaitanaris GA, Gottesman $\mathrm{ME}$, et al. Disruption of the transthyretin gene results in mice with depressed levels of plasma retinol and thyroid hormone. Proc Natl Acad Sci U S A (1993) 90(6):2375-9. doi:10.1073/pnas.90.6.2375

34. Vranckx R, Savu L, Maya M, Nunez EA. Characterization of a major development-regulated serum thyroxine-binding globulin in the euthyroid mouse. Biochem J (1990) 271(2):373-9.

35. Palha JA. Transthyretin as a thyroid hormone carrier: function revisited. Clin Chem Lab Med (2002) 40(12):1292-300. doi:10.1515/CCLM.2002.223

36. Pardridge WM. Plasma protein-mediated transport of steroid and thyroid hormones. Am J Physiol (1987) 252(2 Pt 1):E157-64.

37. Schröder-van der Elst JP, van der Heide D, Rokos H, Morreale de Escobar G, Köhrle J. Synthetic flavonoids cross the placenta in the rat and are found in fetal brain. Am J Physiol (1998) 274(Pt 1):E253-6.

38. Morvan-Dubois G, Fini JB, Demeneix BA. Is thyroid hormone signaling relevant for vertebrate embryogenesis? Curr Top Dev Biol (2013) 103:365-96. doi:10.1016/B978-0-12-385979-2.00013-7

39. Kinne A, Kleinau G, Hoefig CS, Grüters A, Köhrle J, Krause G, et al. Essential molecular determinants for thyroid hormone transport and first structural implications for monocarboxylate transporter 8. J Biol Chem (2010) 285(36):28054-63. doi:10.1074/jbc.M110.129577

40. Braun D, Kim TD, le Coutre P, Kohrle J, Hershman JM, Schweizer U. Tyrosine kinase inhibitors noncompetitively inhibit MCT8-mediated iodothyronine transport. J Clin Endocrinol Metab (2012) 97(1):E100-5. doi:10.1210/jc.20111837

41. Brix K, Fuhrer D, Biebermann H. Molecules important for thyroid hormone synthesis and action - known facts and future perspectives. Thyroid Res (2011) 4(Suppl 1):S9. doi:10.1186/1756-6614-4-S1-S9 Epub 2011/08/13,

42. Pinna G, Meinhold H, Hiedra L, Thoma R, Hoell T, Graf KJ, et al. Elevated 3,5-diiodothyronine concentrations in the sera of patients with nonthyroidal illnesses and brain tumors. J Clin Endocrinol Metab (1997) 82(5):1535-42. doi:10.1210/jcem.82.5.3939

43. Moeller LC, Broecker-Preuss M. Transcriptional regulation by nonclassical action of thyroid hormone. Thyroid Res (2011) 4(Suppl 1):S6. doi:10.1186/ 1756-6614-4-S1-S6 Epub 2011/08/13,

44. Davis PJ, Lin HY, Tang HY, Davis FB, Mousa SA. Adjunctive input to the nuclear thyroid hormone receptor from the cell surface receptor for the hormone. Thyroid (2013) 23(12):1503-9. doi:10.1089/thy.2013.0280

45. Brent GA. Mechanisms of thyroid hormone action. J Clin Invest (2012) 122(9):3035-43. doi:10.1172/JCI60047
46. Ito K, Uchida Y, Ohtsuki S, Aizawa S, Kawakami H, Katsukura Y, et al. Quantitative membrane protein expression at the blood-brain barrier of adult and younger cynomolgus monkeys. JPharm Sci (2011) 100(9):3939-50. doi:10.1002/ jps.22487 Epub 2011/01/22,

47. Schwartz CE, May MM, Carpenter NJ, Rogers RC, Martin J, Bialer MG, et al. Allan-Herndon-Dudley syndrome and the monocarboxylate transporter 8 (MCT8) gene. Am J Hum Genet (2005) 77(1):41-53. doi:10.1086/431313

48. Biebermann H, Ambrugger P, Tarnow P, von Moers A, Schweizer U, Grueters A. Extended clinical phenotype, endocrine investigations and functional studies of a loss-of-function mutation A150V in the thyroid hormone specific transporter MCT8. Eur J Endocrinol (2005) 153(3):359-66. doi:10.1530/eje.1.01980

49. Dumitrescu AM, Liao XH, Best TB, Brockmann K, Refetoff S. A novel syndrome combining thyroid and neurological abnormalities is associated with mutations in a monocarboxylate transporter gene. Am J Hum Genet (2004) 74(1):168-75. doi:10.1086/380999

50. Friesema EC, Grueters A, Biebermann H, Krude H, von Moers A, Reeser M, et al. Association between mutations in a thyroid hormone transporter and severe X-linked psychomotor retardation. Lancet (2004) 364(9443):1435-7. doi:10.1016/S0140-6736(04)17226-7

51. Dumitrescu AM, Liao XH, Weiss RE, Millen K, Refetoff S. Tissue-specific thyroid hormone deprivation and excess in monocarboxylate transporter (mct) 8-deficient mice. Endocrinology (2006) 147(9):4036-43. doi:10.1210/en.20060390

52. Trajkovic M, Visser TJ, Mittag J, Horn S, Lukas J, Darras VM, et al. Abnormal thyroid hormone metabolism in mice lacking the monocarboxylate transporter 8. J Clin Invest (2007) 117(3):627-35. doi:10.1172/JCI28253

53. Müller J, Mayerl S, Visser TJ, Darras VM, Boelen A, Frappart L, et al. Tissuespecific alterations in thyroid hormone homeostasis in combined Mct10 and Mct8 deficiency. Endocrinology (2014) 155(1):315-25. doi:10.1210/en.20131800

54. Mayerl S, Müller J, Bauer R, Richert S, Kassmann CM, Darras VM, et al. Transporters MCT8 and OATP1C1 maintain murine brain thyroid hormone homeostasis. J Clin Invest (2014) 124(5):1987-99. doi:10.1172/JCI70324

55. Kinne A, Schulein R, Krause G. Primary and secondary thyroid hormone transporters. Thyroid Res (2011) 4(Suppl 1):S7. doi:10.1186/1756-6614-4-S1-S7 Epub 2011/08/13,

56. Kinne A, Roth S, Biebermann H, Köhrle J, Grüters A, Schweizer U. Surface translocation and tri-iodothyronine uptake of mutant MCT8 proteins are cell type-dependent. J Mol Endocrinol (2009) 43(6):263-71. doi:10.1677/JME-090043

57. Westholm DE, Marold JD, Viken KJ, Duerst AH, Anderson GW, Rumbley JN. Evidence of evolutionary conservation of function between the thyroxine transporter Oatp $1 \mathrm{cl}$ and major facilitator superfamily members. Endocrinology (2010) 151(12):5941-51. doi:10.1210/en.2010-0640

58. Geier EG, Schlessinger A, Fan H, Gable JE, Irwin JJ, Sali A, et al. Structure-based ligand discovery for the Large-neutral Amino Acid Transporter 1, LAT-1. Proc Natl Acad Sci U S A (2013) 110(14):5480-5. doi:10.1073/pnas.1218165110

59. Lima de Souza EC, Groeneweg S, Visser WE, Peeters RP, Visser TJ. Importance of cysteine residues in the thyroid hormone transporter MCT8. Endocrinology (2013) 154(5):1948-55. doi:10.1210/en.2012-2101

60. Groeneweg S, Lima de Souza EC, Visser WE, Peeters RP, Visser TJ. Importance of His192 in the human thyroid hormone transporter MCT8 for substrate recognition. Endocrinology (2013) 154(7):2525-32. doi:10.1210/en.20122225

61. Groeneweg S, Friesema EC, Kersseboom S, Klootwijk W, Visser WE, Peeters RP, et al. The role of Arg 445 and Asp498 in the human thyroid hormone transporter MCT8. Endocrinology (2014) 155(2):618-26. doi:10.1210/en.2013-1521

62. Kleinau G, Schweizer U, Kinne A, Köhrle J, Grüters A, Krude H, et al. Insights into molecular properties of the human monocarboxylate transporter 8 by combining functional with structural information. Thyroid Res (2011) 4(Suppl 1):S4. doi:10.1186/1756-6614-4-S1-S4 Epub 2011/08/13,

63. Braun D, Lelios I, Krause G, Schweizer U. Histidines in potential substrate recognition sites affect thyroid hormone transport by monocarboxylate transporter 8 (MCT8). Endocrinology (2013) 154(7):2553-61. doi:10.1210/en.2012-2197

64. Friesema EC, Jansen J, Jachtenberg JW, Visser WE, Kester MH, Visser TJ. Effective cellular uptake and efflux of thyroid hormone by human monocarboxylate transporter 10. Mol Endocrinol (2008) 22(6):1357-69. doi:10.1210/me.20070112 
65. Braun D, Wirth EK, Schweizer U. Thyroid hormone transporters in the brain. Rev Neurosci (2010) 21(3):173-86. doi:10.1515/REVNEURO.2010.21.3.173 Epub 2010/10/01,

Conflict of Interest Statement: The authors declare that the research was conducted in the absence of any commercial or financial relationships that could be construed as a potential conflict of interest.

Received: 10 April 2014; accepted: 07 June 2014; published online: 24 June 2014.
Citation: Wirth EK, Schweizer U and Köhrle J (2014) Transport of thyroid hormone in brain. Front. Endocrinol. 5:98. doi: 10.3389/fendo.2014.00098

This article was submitted to Thyroid Endocrinology, a section of the journal Frontiers in Endocrinology.

Copyright (C) 2014 Wirth, Schweizer and Köhrle. This is an open-access article distributed under the terms of the Creative Commons Attribution License (CC BY). The use, distribution or reproduction in other forums is permitted, provided the original author(s) or licensor are credited and that the original publication in this journal is cited, in accordance with accepted academic practice. No use, distribution or reproduction is permitted which does not comply with these terms. 